Результаты деятельности позволяют нам констатировать эффективность взаимодействия детского сада и семьи. Изменилось мировоззрение многих родителей о своевременности и необходимости формирования исторических представлений у дошкольников об историческом прошлом.

$$
* * *
$$

1. Горячев А.В. Проектная деятельность в образовательной системе «Школа 2100» // Журнал «Начальная школа. Плюс: до и после», 2004, № 5

2. Елизарова Н.М., Колесникова О.А. Молодой учёный № 24 (128), ноябрь 2016.

3. - Матова В. Н., Краеведение в детском саду. - СПб.: ООО Издательство «ДЕТСТВО-ПРЕСС», $2015-176 \mathrm{c}$.

4. Маханева М.Д. Нравственно-патриотическое воспитание детей старшего дошкольного возраста: Пособие для реализации Государственной программы «Патриотическое воспитание граждан Российской Федерации на 2001-2005 годы». - М.: АРКТИ, 2005.

5. Патриотическое воспитание дошкольников средствами краеведо-туристской деятельности: Пособие для реализации государственной программы «Патриотическое воспитание граждан Российской Федерации на 2001-2005 годы» / Под ред. А.А. Остапца, Г.Н. Абросимовой, М.Е. Трубачевой. - М.: АРКТИ, 2004.

6. Алгоритмы реализации регионального компонента «патриотическое воспитание» ООП ДО в ДОУ [Текст] : учеб.-метод. пособие / Под ред. О.В. Дыбиной. - Ульяновск: Издатель Качалин Александр Василевич, $2013-214$ с.

\title{
Саакян P.C. \\ Лингвопсихологический аспект развития русской речи учащихся средствами произведений живописи
}

Абхазский государственный университет (АГУ)

(Абхазия, Сухум)

doi 10.18411/gq-31-07-2021-16

\section{Аннотация}

В статье представлено научное понимание проблемы номинации эмоционального состояния человека. Особое внимание уделено анализу лексикосемантических групп слов, актуальных для вербализованной интерпретации художественных достоинств картины.

Систематизированные автором лексические средства, потенциально значимые для развития речи учащихся средствами живописи, обогащают методику преподавания русского языка в школах Абхазии.

Ключевые слова: многозначные слова, лексико-семантические группы слов, интерпретация, вербализация, художественное достоинство картины, лексические средства, принципы обучения, развитие речи, принцип обучения в деятельности.

\section{Abstract}

The article presents a scientific understanding of the problem of nominating the emotional state of a person. Special attention is paid to the analysis of lexical and semantic groups of words relevant for the verbalized interpretation of the artistic merits of the picture.

The lexical means systematized by the author, which are potentially significant for the development of students ' speech by means of painting, enrich the methodology of teaching the Russian language in schools of Abkhazia.

Keywords: polysemous words, lexico-semantic groups of words, interpretation, verbalization, artistic dignity of the picture, lexical means, principles of learning, speech development, the principle of learning in activity.

Анализ литературы по вопросам понимания школьниками художественной картины мира в произведениях живописи позволил уточнить содержание и структурирование работы по осмыслению школьниками: 
- творческого пути художника;

- специфики его уникального и оригинального стиля профессиональной деятельности;

- личностных качеств (жизнелюбие, трудолюбие и др.);

- склонностей к межличностному общению, внутреннему диалогу (аутодиалогу);

- привычек, поведения, характера;

- устойчивости или динамичности настроения.

Такая направленность работы по развитию речи, по обучению всем видам речевой деятельности поддерживается целевым отбором актуальной лексики со значением «личные достоинства человек». Данные лексические материалы устанавливались с учётом описания феноменов «культура мира», «культура достоинства» (А.Г. Асмолов, Кудрявцев, Н.Д. Никандров и др.):

- доброта (честность, мягкость, отзывчивость, стойкость, сострадательность, вера, жизнелюбие, заботливость, искренность, порядочность);

- настойчивость (упорство, тактичность, отходчивость, вежливость, оптимизм, обязательность, терпимость, трудолюбие, доверчивость, смирение, решительность, скромность);

- ответственность (спокойствие, сдержанность, усидчивость, правдивость, восприимчивость, дружелюбие, ироничность, твёрдость, тактичность, добросовестность);

- способность к общению (открытость, щепетильность, дальновидность, увлечённость, щедрость, рассудительность, уверенность в себе, сосредоточенность, внимательность, покладистость).

Соглашаясь с выводами учёных о необходимости перехода в обучении русскому языку в контекст обучения речевой деятельности - рецептивной и продуктивной, обратим внимание на решение в науке задач обогащения словарного запаса. Прежде всего - необходимо определить специфику работы над новыми словами. Один из постулатов работы над новыми словами определяет требование чёткого понимания лексического значения слова, его грамматических характеристик, стилистических ресурсов. К обязательным условиям освоения новых слов справедливо относится введение нового слова в структуру словосочетания, предложения, текста, а также оценивание правильности, уместности его использования в готовом (авторском) тексте. Такие ориентиры в работе над новой лексикой соответствуют принципу целостности обучения речевой деятельности в её разновидностях (рецептивные - чтение, аудирование, продуктивных - письмо, говорение, принципу обучения в деятельности).

Словарная работа на уроках русского языка и развития речи подчинена законам, исходящим из выводов Л.С. Выготского о том, что слова в памяти нашей хранятся смысловыми блоками. Следуя такой максиме, при анализе авторских текстов, тематически соответствующих интерпретации дидактических и эстетических ресурсов произведений живописи, в организации работы над словом учитывались взгляды лингвистов, социологов, психологов, методистов на природу формирования в языке и реализацию в тексте слов со значением «сферы жизнедеятельности человека», а именно:

- психологическая сфера - эмоции, чувства, самооценка, интеллект, внимание, память, мышление, воля человека;

- социальная сфера - взаимоотношения с людьми, авторитет, репутация, доверие, амбиции, ответственность, уважение другого и других; самоуважение; 
- духовная сфера - вера, надежда, любовь, терпение, принятие, сопереживание, забота о близких, морально-нравственные ценности, трудолюбие, жизнелюбие, благодарение.

Анализ научной литературы по теме диссертационного исследования «Развитие русской речи учащихся школ Абхазии средствами произведений живописи» позволяет согласиться с выводами учёных о недостаточном внимании к работе над словами со значением негативной оценки, отражающей антонимичную пару «прекрасное» «безобразное».

Работа над словами со значением «безобразное» характеризуется специфическим содержанием, адекватно отражающим их лексическое значение: как взаимообусловленный антипод идеалу, прекрасному; как эстетическое переживание зла и хаоса, нарушение чувства меры, «низменное» (крайняя степень безобразного, разрушающего и уничтожающего жизнь).

Актуальны для нашего исследования материалы, сформированные лингвистами, методистами, психологами по структурированию лексико-семантических групп, объединяющих лексемы со значением «дефекты характера» человека, например: зависть, подозрительность, мстительность, лень, безответственность, небрежность, упрямство, злорадство, нечестность, угодливость, лицемерие, несдержанность, трусость и др. В этой связи важно было уточнить содержание понятия «лексикосемантическая группа» - как:

- $\quad$ важнейшего способа систематизированного представления лексического богатства языка;

- единицы описания языковой картины мира.

Нельзя сбрасывать со счетов то, что лексико-семантические группы, объединяющие слова одной части речи, отражают регулярность связей слов, тождественных по семантике, но отличающихся лексическим значением. Это определяет их функциональное предназначение отражать тематику текста, укреплять связность его структурных компонентов: зачин (начало), основную часть, концовку (конец), формировать микротемы, сложные синтаксические целые (ССЦ).

Работа по развитию речи конкретизируется определением педагогических условий успешного обучения всем видам речевой деятельности - рецептивным (восприятие и осмысление речевого высказывания, текста через аудирование и чтение), продуктивным (создание речевого высказывания через говорение и письмо). Справедливы устойчивые выводы учёных об обязательном формировании эмоционального фона для успешной учебной деятельности (Н.Б. Экба, А.М. Касландзия, А.Х. Загаштоков, И.А. Шаповалова и др.). Это по-особому значимо в работе по развитию речи средствами произведений живописи: в каждом из таких произведений априори закодированы эмоции, переживания, настроения, отношения художника - автора картины. Включение и участие школьников в реальных и виртуальных событиях, соответствующих содержанию картины, мотивирует переживание ими базовых эмоций страха, гнева, печали, радости, что реализуется в активности использования ими богатейших ресурсов лексико-семантических групп со значением «эмоциональные переживания».

Например, переживание эмоции страха отражается употреблением в речи говорящего или пишущего таких слов, как робость, настороженность, кротость, беззащитность, ужас, тревожность, трепет, обеспокоенность, испуг, тревога, волнение, стресс, боязнь, смятение, растерянность и др.

Пребывание человека в эмоциональном состоянии «печаль» подчёркивается использованием слов грусть, отчаяние, ранимость, подавленность, разочарование, покинутость, подавленность, одиночество, усталость, апатия, уныние, хандра, скорбь, ностальгия, безучастность. 
Эмоция «радость» раскрывается через возможность целесообразного выбора ситуативно актуального слова из ряда возможных: успех, удача, радушие, умиротворение, счастье, эйфория, восторг, блаженство, удовольствие, мечтательность, очарованность, надежда, взволнованность, возбуждённость, энтузиазм, удовлетворённость, живость, облегчение, окрылённость, одухотворённость, ликование, благодарность, нежность, симпатия, предвкушение, ожидание, приподнятость [3;6;9;].

В трудах Р. Плутчика, П. Экмана, С. Томкинса, Кэролла Изарда кроме указанных выше базовых эмоций выделяются также эмоции:

- «удивление» (опасение, ошеломлённость, шок, оторопь, остолбенение, изумление, потрясение, впечатлительность);

- «отвращение» (недовольство, подозрительность, циничность, настороженность, озабоченность, презрение, уязвлённость, скука, неприязнь, надменность).

В системе основных эмоций Р. Плутчик и С. Томкинс рассматривают также эмоцию «интерес», предполагающую переживание любопытства, азарта, увлечения, увлечённости, вдохновения, воодушевления, драйва, заинтересованности, желания, страсти, обожания, очарованности, преклонения, значимости, важности). В этой связи учёные обращаются к описанию эмоциональных переживаний человека, участвующего в процессе обучения, к анализу специфики проявления инициативности, адаптивности, адекватности поведенческих реакций, дальновидности коммуникативных стратегий и тактик, уверенности при аргументации выводов, рассудительности и сосредоточенности, без игнорирования, готовности к взаимопониманию и сотрудничеству.

С. Томкинс, П. Экман, Кэррол Изард не оставляют без внимания трактовку такой эмоции, как «стыд», связанную с переживанием неудовольства, неловкости, застенчивости, смущения, пристыженность, угрызения совести, замешательства [3;6;9].

Как известно, на возрастном этапе подростка школьники нередко оказываются в ситуациях переживания застенчивости, неловкости, смущения, замешательства, причины которых иногда кроются в психологии «гадкого утёнка» - быстро изменяющихся физиологических характеристиках, не совпадающих с представлением ребёнка о совершенствовании внешности, пропорций телосложения, «красивого» лица. Такие переживания заметили и описали в произведениях художественной литературы Ф. Искандер, В. Железникова, П. Санаев, К. Кулиев, Н. Хубиев, Т. Керашев, Х. Хапсироков, И. Машбаш, Б. Васильев, в живописи - А. Пластов, Е. Сыромятникова, Т. Яблонская, И. Попов, Широков, С. Григорьев, В. Хабаров, В. Репка, Ю. Пименов, Ф. Решетников и др.

Очарованность, надежда, взволнованность, живость, окрылённость, ожидание, приподнятость и др.

Представление слов со значением «эмоциональное состояние», ограниченное их отнесённостью к именам существительным (в выше представленном лингвистическом материале) в условиях педагогического эксперименте укреплялось их возможностями отражать «словообразовательные гнёзда», например: печаль - печальный, печалиться; обида - обидеть, обиженный, обидчивый, обижающий и др.

Значимость произведений художественной литературы и живописи о жизни подростка переоценить невозможно. Писатели и художники формируют отношение растущего ребёнка к красоте человека - внешней и внутренней — в пользу внутренней, признающей ценность и самоценность духовно-нравственного богатства людей на всех этапах их возрастных изменений.

Характеристика эмоционального состояния человека, воспринимающего произведения живописи предполагает уточнение возможностей воздействия картины на его настроение. В психологии феномен настроение рассматривается в ряду понятий об общем эмоциональном состоянии человека. Настроение, отмечают психологи, 
меняется под влиянием конкретных событий, обстоятельств, стимулирующих переживания позитивного (хорошее настроение) или негативного (плохое настроение). У слова «настроение», обозначающего известное явление эмоционального состояния человека, богаты синтаксические связи, возможности грамматической и лексической сочетаемости с именами прилагатеьными. Приведём пример имён прилагательных, причастий, сочетающихся по смыслу и согласовывающихся грамматически со словом, понятием настроение: бодрое, весёлое, волшебное, восторженное, возбуждённое, грустное, добродушное, жуткое, загадочное, капризное, радостное, светлое, сказочное, серьёзное, солнечное, сонное, сосредоточенное, спокойное, таинственное, тихое, мечтательное, мрачное, печальное, торжественное, тоскливое, тревожное и др.

Анализ трудов, посвящённых проблеме отражения художественной картины мира автором произведения живописи в логике нашего исследования соотнесён с результатами наблюдения педагогического процесса по формированию у школьников готовности к художественному восприятию картины мира. Так, в эксперименте были объединены важные направления исследовательской деятельности: изучение научной литературы и осуществление наблюдений педагогического процесса, адресно ориентированные, с одной стороны, на творческое отражение автором художественной картины мира в своём произведении, с другой - на восприятие художественной картины мира учеником - зрителем, рассматривающем произведение живописи и впоследствии - представляющем своё понимание, интерпретацию картины в доступном ему виде творческой деятельности - речевой (письмо, говорение). Отметим, в своём тексте школьник представляет личностное осмысление, понимание произведения живописи. Однако вербализовать это понимание в доступной форме интерпретации, трактовки могут далеко не все дети. Тем не менее, многие из них в своей речи обращаются к попытке «по-своему» объяснить интерес художников к природе родного края, что, по их мнению, открывает возможность «рассказать зрителям» об отношении к родине, о любви к жизни, её многообразия, но целостности в едином мире человека.

$* * *$

1. Асмолов А.Г. Психология личности: культурно-историческое понимание развития человека. - М.: Смысл, 2007

2. Кудрявцев В.Т. Культура как самоотношение . // Культурно-историческая психология/ - 2016. Т.12, №3. - С. 113-128.

3. Кэролл Изард. Психология эмоций. - СПб.: Питер, 1999. - 460 с.

4. Никандров Н.Д. Россия: социализация и воспитание на рубеже тысячелетий. - М.: 2000

5. Пантилеев С.Р., Визгина А.В., Зимачева Е.М. Способы вербальной презентации образа «я» и самоотношение субъекта. // Психологическое обозрение. - 1997, №2. С. 27-30

6. Плутчик Р. Теории эмоций. - Нью-Йорк: Academic Press, 1980

7. Шадриков В.Д. Духовные способности. - М.: Магистр, 1988

8. Шаповалова И.А. Научно-исследовательская деятельность субъектов образовательного процесса как условие развития художественного вуза // Журнал педагогических исследований, 2020, т. 5, №1. - C. 3-7

9. Экман П. Психология эмоций. - СПб.: Питер, 2010 - 336с.

\section{Скоробогатова О.Ю.}

Научно-исследовательская деятельность субъектов образовательного процесса (на примере Института традиционного прикладного искусства ФГБОУ ВО «Высшая школа народных искусств (академия)»

Высшая школа народных искусств (академия) (Россия, Санкт-Петербург)

doi 10.18411/gq-31-07-2021-17

\section{Аннотация}

Статья посвящена проблеме деятельности Института традиционного прикладного искусства Высшей школы народных искусств (академии). Автор 